\author{
Vote-by-Mail: Voter Preferences and \\ Self-Reported Voting Behavior in the State of Oregon
}

\title{
Priscilla Southwell
}

This research analyzes the results of a recent survey in Oregon in order to assess recent opinion on vote-by-mail and also to estimate the effect of vote-by-mail on the turnout of various demographic and partisan groups. The results show that Oregonians have maintained their overwhelming support for vote-by-mail elections - in particular, women, Independents, Republicans, and older voters. Self-reported responses regarding frequency of voting indicate that women and the employed are most likely to indicate that they have voted more often since the adoption of vote-bymail. This survey also suggests that this increased turnout under vote-by-mail does not give an advantage to a particular party's candidates.

In January 1996, the State of Oregon held a special election to replace Senator Bob Packwood. The special nature of this election allowed for the use of a vote-by-mail format - a method of conducting elections that the state had been using for non-candidate elections since 1981. The Oregon League of Women voters led a successful petition drive to put vote-by-mail on the 1998 general election ballot, and this measure passed by a 67 percent margin. Since that time, all elections in Oregon have been conducted by mail. ${ }^{1}$

Debate over all-mail elections exists for numerous reasons, but a certain portion of this controversy has arisen from the uncertainty of the impact of vote-by-mail on the nature of the electorate. ${ }^{2}$ Does vote-by-mail work to the advantage of one political party over another? Does this electoral method facilitate voting among certain demographic groups. Vote-bymail is also quite popular among Oregon residents, and public opinion polls show overwhelming support for this type of election (Southwell and Burchett 1997; Traugott, 1996). Based on a 2003 survey, this research examines which groups, if any, indicate that they vote more often under vote-by-mail and which groups are more likely to favor this method of voting as compared to the traditional polling place method.

\section{Composition of the Electorate and Vote-by-Mail}

Previous research on the impact of vote-by-mail on the nature of electorate has generally found that vote-by-mail facilitates the participation of

PRISCILLA SOUTHWELL is a professor of political science at the University of Oregon.

The American Review of Politics, Vol. 28, Summer, 2007: 139-146

(C)2007 The American Review of Politics 
likely voters rather than drawing nonvoters into the electorate. Karp and Banducci (2000) conclude that vote-by-mail increases turnout among those who are already predisposed to vote, (i.e., those with higher socioeconomic status). Berinsky et al. (2000) found that vote-by-mail increased participation among well-educated older voters and those with a high degree of interest in the campaign - leading them to conclude that vote-by-mail makes it "easier for current voters to continue to participate, rather than mobilizing nonvoters into the electorate" (p. 178). Similarly, Southwell and Burchett (2000) found that "vote-by-mail" voters, that is, those that were more likely to vote because of an all mail format, more closely resembled the demographic and attitudinal profile of "traditional" voters rather than nonvoters.

\section{Data and Methods}

This research uses data from the Oregon Annual Social Indicators Survey, conducted by the Oregon Survey Research Laboratory at the University of Oregon. A random-digit-dialing (RDD) survey of 1037 individuals in the state of Oregon was conducted between December, 2002 and January $2003 .^{3}$ For the purposes of this study, only registered voters $(n=695)$ were analyzed. See the Appendix for variable coding.

\section{Analysis of Preference for Vote-by-Mail versus Polling Place Elections}

The 2003 survey of Oregon voters included a question asking respondents whether they preferred vote-by-mail or the polling place as a method of conducting elections. Because any multivariate analysis involves a dichotomous dependent variable, certain OLS assumptions are violated; therefore probit analysis is used to estimate the effect of each demographic or attitudinal variables on preference for vote-by-mail or polling place elections. ${ }^{4}$ Probit estimates (MLEs) are presented in Table $1 .{ }^{5}$

The results show that certain subgroups display a distinctly higher preference for vote-by-mail. After controlling for other demographic and attitudinal factors, women, older, and non-Democratic voters were more likely to favor vote-by-mail over polling place elections.

\section{Analysis of Impact of Vote-by-Mail on Frequency of Voting}

This survey question, of course, only deals with preference, and it is equally important to determine if these preferences have any effect on subsequent voting behavior. Ideally, we would be able to track the voting patterns of registered voters over many elections, and compare their voting history across both polling place and vote-by-mail elections, after controlling for the 
Table 1. Probit Analysis of Preference for Vote by Mail over Polling Place Elections

\begin{tabular}{llll}
\hline Variable & MLEs & Variable & MLEs \\
\hline Female & $.354^{* * *}$ & Nonwhite & -.105 \\
& $(.096)$ & & $(.158)$ \\
Age & $.011^{* * *}$ & Education & .032 \\
& $(.002)$ & & $(.046)$ \\
Independent & $.381^{* * *}$ & Income & .013 \\
Republican & $(.128)$ & & $(.027)$ \\
& $.282^{* *}$ & Liberal & .053 \\
Employed & $(.121)$ & & $(.170)$ \\
& .030 & Conservative & .113 \\
Suburban & $(.106)$ & & $(.156)$ \\
& -.008 & Constant & $-.585^{* *}$ \\
& $(.099)$ & & $(.234)$
\end{tabular}

Note: The dependent variable is coded " 1 " for those who prefer vote by mail ( $81 \%$ of respondents) and " 0 " for those who prefer polling place elections; (19\%) Numbers in parentheses are standard errors; $\mathrm{N}=797 ; * * \mathrm{p}<.05 ; * * * \mathrm{p}<.01$; Aldrich-Nelson pseudo- $\mathrm{R}^{2}=.47$; Source: 2003 Oregon Annual Social Indicators Survey.

context of each election. ${ }^{6}$ However, Oregonians, similar to most Americans, are quite transitory in nature, and the ability to capture a stable set of registered voters over a reasonably long time period is close to impossible.

Instead, we have relied on the survey respondents' assessments of the effect, if any, of vote-by-mail on their rate of participation. Respondents were asked whether they had voted "more often," "less often," or "about the same" since Oregon started conducting its elections by mail. Table 2 provides a probit analysis of the relationship between this variable and the standard demographic and partisan variables. Only the gender and employment variables reach statistical significance.

Women, and those who are employed, both reported that they vote more often since the adoption of vote-by-mail in the state. Of course, this survey question did not indicate if this increased level of participation under vote-by-mail occurred in a particular type of election. Given the previous findings of Karp and Banducci (2001), it is likely that a good portion of this elevated turnout occurred in low-stimulus or local elections.

In this analysis, we also included measures of reported vote in various races at the national and state level, but there was no discernible difference with regard to partisan identification or candidate preferences. All other demographic variables have little explanatory power. 
Table 2. Probit Analysis of Self-Reported Effects of Vote by Mail on Turnout

\begin{tabular}{llll}
\hline Variable & MLEs & Variable & MLEs \\
\hline Female & $.354^{* * *}$ & Nonwhite & -.105 \\
& $(.096)$ & & $(.158)$ \\
Female & $.386^{* * *}$ & Independent & .136 \\
& $(.104)$ & & $(.139)$ \\
Employed & $.322^{* * *}$ & Liberal & -.179 \\
& $(.114)$ & & $(.187)$ \\
Suburban & .184 & Conservative & .032 \\
& $(.104)$ & & $(.164)$ \\
Age & -.005 & Voted for Republican & .109 \\
& $(.003)$ & Senate Candidate & $(.139)$ \\
Nonwhite & -.278 & Voted for Republican & -.030 \\
& $(.175)$ & Gubernatorial Candidate & $(.165)$ \\
Education & -.057 & Voted for Bush in 2000 & .021 \\
Income & $(.049)$ & & $(.142)$ \\
& -.024 & Constant & $-.694 * *$ \\
Republican & $(.029)$ & & $(.254)$ \\
& -.021 & & \\
& $(.170)$ & &
\end{tabular}

Note: The dependent variable is coded " 1 " for those who indicated that they voted "more often" since the adoption of vote by mail ( $24.5 \%$ of respondents) and " 0 " for those who said they voted the "about the same" or "less often" (75.5\%); Numbers in parentheses are standard errors; $N=797$; ${ }^{* *} \mathrm{p}<.05 ; * * * \mathrm{p}<.01$. Aldrich-Nelson pseudo- $\mathrm{R}^{2}=.33$; Source: 2003 Oregon Annual Social Indicators Survey.

The comparison of the probit analyses in Tables 1 and 2 shows that preference and voting behavior display distinctly different patterns for certain groups. Although older, Republican voters showed a distinct preference for vote-by-mail, they do not appear to vote more often under this type of election. Perhaps these individuals had utilized an absentee ballot in the past, and so their participation had not increased as a result of vote-by-mail. However, these individuals still favored vote-by-mail because of their use of absentee voting in the past. Although employed voters were not any more likely to favor vote-by-mail, as compared to others with a different employment status, they indicated that vote-by-mail elevated their level of participation. Women, however, were consistent in both their preference for vote-bymail and their view that they voted more often as a result of this reform. As suggested by Traugott (1996) and Southwell and Burchett (1997), many 
women, especially those with children at home, expressed a preference for vote-by-mail because it allowed them to vote despite their somewhat hectic lifestyles.

\section{Conclusions}

After five years, we can conclude that Oregon's experiment with voteby-mail has been in place long enough for voters to have made a thoughtful assessment of this electoral reform. It appears that their initial enthusiasm for vote-by-mail has not diminished. Although this survey cannot provide an empirical test of how accurate is their assessment on the impact of vote-bymail on their level of turnout, a sizable minority of its citizens feel that voteby-mail has increased their rate of participation. For most Oregonians, however, vote-by-mail simply keeps them on the path of consistent participation, therefore supporting the findings of Berinsky et al. (2001) and Karp and Banducci (2000).

Since these findings do not uncover any party preference among those voters who feel vote-by-mail has increased their participation, this electoral reform may avoid the usual pitfall of partisan conflict, as occurred over the "motor voter" bill during the previous decade. Furthermore, education appears to have little effect in affecting turnout under vote-by-mail, so the concern about a "dumbing down" of the electorate is unfounded. In short, vote-by-mail seems to appeal to all types of voters, and enhance the participation of many different types of citizens. ${ }^{7}$

\section{APPENDIX}

Variable Coding

Voting since Vote-by-Mail "The State of Oregon began using an all mail format for some of its elections in 1981. Since 2000 Oregon has used vote-by-mail for all of its elections. Since Oregon stated vote-by-mail, have you voted more often, less often, or about the same?"

Dummy variable created for voted more often. (1, otherwise 0 )

Preference for Election Type "Which type of election do you prefer - vote-by-mail or polling place?" Dummy variable created for vote-by-mail. (1, otherwise 0$)$

Gender (Female) $\quad 1$ if female; 0 if male

Age 18-96 or older 
APPENDIX (continued)

\begin{tabular}{|c|c|}
\hline Variable & Coding \\
\hline Partisanship & $\begin{array}{l}\text { "Do you consider yourself to be a Democrat, Republican, } \\
\text { Independent, or some other party?" } \\
\text { Dummy variables created for each category. }\end{array}$ \\
\hline Employment Status & $\begin{array}{l}\text { "Are you currently working for pay, either full or part } \\
\text { time?" If no, "Are you retired, looking for work, keeping } \\
\text { house, taking classes, disabled, or something else?" } \\
\text { Dummy variables created for each category. }\end{array}$ \\
\hline Locale & $\begin{array}{l}\text { "Do you live in an urban area, a suburban area, or a rural } \\
\text { area? } \\
\text { Dummy variables created for each category. }\end{array}$ \\
\hline Race (Nonwhite) & 1 if nonwhite/non-Caucasian; 0 if white or Caucasian \\
\hline Education & $\begin{array}{l}1=\text { Less than high school } \\
2=\text { High school diploma } \\
3=\text { Some college or A.A. or A.S } \\
4=\text { B.A. or B.S } \\
5=\text { Advanced degree }\end{array}$ \\
\hline Income & $\begin{array}{l}1=\text { Less that } \$ 18,000 \\
2=\$ 18,000-\$ 25,000 \\
3=\$ 25,001-\$ 40,000 \\
4=\$ 40,001-\$ 70,000 \\
5=\$ 70,001-\$ 100,000 \\
6=\text { Over } \$ 100,000\end{array}$ \\
\hline Ideology & $\begin{array}{l}\text { "When it comes to politics, do you think of yourself as con- } \\
\text { servative, moderate or middle of the road, or liberal?" } \\
\text { Dummy variables created for each category. }\end{array}$ \\
\hline Vote for Governor 2002 & $\begin{array}{l}\text { "Thinking back to the November election, for whom did } \\
\text { you vote in the governor's race? } \\
\text { Dummy variables created for each category. }\end{array}$ \\
\hline Vote for Senate 2002 & For whom did you vote in the U.S. Senate race? \\
\hline Vote for President 2000 & For whom did you vote in the 2000 presidential race? \\
\hline
\end{tabular}

\section{NOTES}

${ }^{1}$ State of Oregon. Office of the Secretary of State. Election Report, 1960-2004. State of Oregon. Office of the Secretary of State. Oregon's Special Senate by Mail, November 11, 1996.

${ }^{2}$ See San Francisco Chronicle (1996); Washington Post (1996); New York Times (1996); Jeffe and Jeffe (1990). The possibility of voter fraud is also a concern of opponents of vote-by-mail elections. See Will (1995); Ornstein (1996); Jacoby (1996). 
${ }^{3}$ The response rate was $62.28 \%$. More information about the survey methodology can be obtained from The Oregon Survey Research Laboratory, 5245 University of Oregon, Eugene, OR 97403-5245 or at http://osrl.uoregon.edu.

${ }^{4}$ The following equation was estimated: $\operatorname{Pr}\left(Y_{i}=1\right)=\operatorname{Pr}\left(a+B_{1} X_{i}+\ldots+B_{j} X_{k}\right)$. $Y_{i t}$ is one if individual i preferred vote-by-mail and zero if preferred polling place elections, and Pr denotes a probability to be estimated.

${ }^{5} \mathrm{~A}$ correlation matrix of these independent variables. The only significant results were between Sex and Party Affiliation (-.130), and Sex and Employment Status (.125).

${ }^{6}$ Berinsky et al. (2001) did this type of analysis over a 20 -month period, from May 1994 to January 1996. While this research provided a preliminary look at the effect of vote-by-mail on turnout, the three vote-by-mail elections in this time period were not typical of Oregon elections - that is, they were either special elections or included only referenda. Since this time, Oregon has conducted four elections by mail-a midterm and presidential primary, and a midterm and presidential general election.

${ }^{7} \mathrm{~A}$ final caveat, however. This study centers on one state - a state that has a "moralistic" culture (Elazar, 1984) and with a relatively high level of turnout, before and after the adoption of vote-by-mail. As Berinsky et al. (2001, 13-14) point out, the relationship between individual-level demographic variables and partisanship can vary among states, due to such factors as level of campaign interest or longevity in the state.

\section{REFERENCES}

Berinsky, Adam, Nancy Burns, and Michael W. Traugott. 2001. Who Votes by Mail? A Dynamic Model of the Individual-Level Consequences of Voting-by-Mail Systems. Public Opinion Quarterly 65: 178-197.

Elazar, Daniel. 1984. American Federalism: A View from the States, 3rd ed. New York: Harper \& Row.

Jacoby, Jeff. 1996. Election By Mail? Here's a No Vote. The Boston Globe, 1 February.

Jeffe, Douglas and Sherry Bebitch Jeffe. 1990. Absence Counts: Voting by Mail. The American Enterprise 1:19-22.

Karp, Jeffery A and Susan A. Banducci. 2001. Absentee Voting, Mobilization, and Participation. American Politics Research 29:183-195.

Karp, Jeffery A and Susan A. Banducci. 2000. Going Postal: How All-Mail Elections Influence Turnout. Political Behavior 22:223-239.

New York Times. 1996. Mail-In Democracy. 8 February.

Oregon Annual Social Indicators Survey. 2003. Eugene, OR: Oregon Survey Research Laboratory, University of Oregon.

Ornstein, Norman. 1996. A Vote Cheapened. The Washington Post, 8 February.

San Francisco Chronicle. 1996. Vote-By-Mail is a Winner. 2 February.

Southwell, Priscilla L. and Justin Burchett. 1997. Survey of Vote-by-Mail Senate Election in the State of Oregon. PS: Political Science and Politics 91:53-57.

Southwell, Priscilla L. and Justin Burchett. 2000. Does Changing the Rules Change the Players? Vote-by-Mail and the Composition of the Electorate. Social Science Quarterly 81:837-845.

State of Oregon. Office of the Secretary of State. Election Report, 1960-2004.

State of Oregon. Office of the Secretary of State. 1996. Oregon's Special Senate by Mail, 11 November. 


\section{6 | Priscilla Southwell}

Traugott, Michael. W. 1996. Report on the Characteristics of the Oregon Electorate Participating in the Special General Election for the U.S. Senate on January 30, 1996. Ann Arbor, MI: Institute for Social Research.

Washington Post. 1996. Oregon's New Idea. 5 February.

Will, George. 1995. Mail Vote Subverts Democracy. Register-Guard, 26 October. 